\title{
Strategic Deviance and Accounting Conservatism
}

\author{
Rui Wang \\ School of Management, Department of Accounting, Jinan University, Guangzhou, China \\ Email:wr1910@163.com
}

How to cite this paper: Wang, R. (2018) Strategic Deviance and Accounting Conservatism. American Journal of Industrial and Business Management, 8, 1197-1228. https://doi.org/10.4236/ajibm.2018.85082

Received: April 12, 2018

Accepted: May 18, 2018

Published: May 21, 2018

Copyright (C) 2018 by author and Scientific Research Publishing Inc. This work is licensed under the Creative Commons Attribution International License (CC BY 4.0).

http://creativecommons.org/licenses/by/4.0/

\begin{abstract}
This paper considers the influence of corporate strategic positioning on the firm's accounting conservatism from the perspective of a company's deviation from the industry's conventional strategy, and selects China's A stock market company as an initial research sample for empirical analysis from 2000 to 2016. Research shows that the greater the company's strategic differences, the lower the accounting conservatism. Further studies have found that the negative correlation between corporate strategic differences and accounting conservatism is even more pronounced in private enterprises. In addition, from the perspective of the intensity of industry rules, this paper compares the degree of strategic deviance between state-owned enterprises and private enterprises, the results show that state-owned enterprises are subject to stronger constraints and the degree of strategic differences will be lower. This article focuses on the perspective of corporate strategic deviance and examines the role of non-accounting information in corporate accounting practices, and compares the strategic differences between state-owned enterprises and private enterprises from the perspective of the strength of industry constraints, which provides an effective means for the company's external stakeholders, including creditors and investors, to use the company's strategic information, and enriches the research on the reform of China's property rights system.
\end{abstract}

\section{Keywords}

Strategic Deviance, Accounting Conservatism, Property Right

\section{Introduction}

At present, the international economic policy situation is undergoing a profound transformation. The United States implements tax reduction plans and accelerates the return of local enterprises, the $\mathrm{EU}$ intends to end quantitative easing, 
the UK has a far-reaching impact on Brexit, and domestic countries are picking up the leverage to guide the economy to "take off the virtual reality". The crazy expansion of China's debt in the past few years has resulted in a huge layer of real estate leverage, government debt, and large-scale asset management systems. Under the macroeconomic background of de-leveraging and credit tightening, the cost of financing has steadily increased.

In recent years, there have been some long-term trend changes in China's industrial structure. Traditional industries dominated by heavy industries are gradually declining, while high-end manufacturing and modern service industries have emerged. In the initial period of transition, as the proportion of old growth drivers is still relatively large, corporate profits and macroeconomics may face downward pressure in a certain period during the process of gradual recession. With the accumulation of human capital, investment in innovation and research, the industrial structure will be upgraded from heavy industry to high-end manufacturing and modern service industries, and the economy will gradually enter a new normal state of stability and sustainable development.

Under this background and reform, the opportunity for Chinese enterprises to seek transformation lies in recognizing the general trend of economic transformation and industrial upgrading, focusing on the optimization of internal resource allocation in enterprises, boldly breaking through traditions, and seeking changes.

Meyer and Rowan (1977) found that while an industry is developing and maturing, the industry will gradually develop a subtle and strategic style, which can be called the "rules" of the industry [1]. The formation of such "rules" is not only be influenced by the internal interactions, but may also be influenced by external influences. For example, the government or other regulatory authorities will often adjust the industry to regulate and control the macro economy. Additionally, if an industry chooses to monopolize its position, it will formulate certain industry-wide uniform rules that directly or indirectly affect the implementation and planning of corporate strategies, such as the OPEC coalition, etc.

The strategic deviance in corporate refers to the trend that a company's strategy deviates from its industry center in the process of enterprise integration. As a result of industrial integration, most companies follow a similar strategy, so there is a central trend. Many companies are inseparable from the central trend of an industry, but some companies have deviated from this central trend in the process of industrial integration, we call it a strategic deviance, which can be understood as the abnormality of a company's strategy and the strategies commonly used in the industry. According to the new institutional theory, companies generally tend to follow industry rules to obtain certain resources and legitimacy, reduce uncertainty, and enhance their ability to survive [1]. In a stable economic environment, such a strategy may be feasible to a certain extent. However, in the current ever-changing external environment, many companies have to change the conventional strategic model and hope to gain a foothold in the increasingly competitive environment, instead of being ruthlessly eliminated 
because of conservative and backward corporate strategies.

However, in the process of seeking a differentiated strategy, enterprises will inevitably have a series of impacts. On the one hand, companies which adopting a deviant strategy will often increase the company's business risk, and thus will also take accounting measures which deviating from the conservatism [2]. On the other hand, regular companies in the industry tend to be conservative, and are more likely to adopt more cautious accounting principles in order to reduce litigation risk and uncertainty, thereby enhancing the company's accounting conservatism.

Currently there is no article in the academia linking corporate strategic deviance with accounting conservatism. Therefore, this paper attempts to study the impact of the company's deviation from the industry's conventional strategy on accounting conservatism, and provide an effective means for external stakeholders to recognize and use corporate strategic information, as well as provide a new perspective for regulators.

The main research framework of this paper is as follows: The first chapter is the introduction, which is mainly to elicit the problems of this paper, discusses the background of the writing of this paper and the significance of the research, later elaborates the main research framework and research methods of the paper, and points out the possible contributions and deficiencies of the paper. The second chapter is the concept definition and literature review. The third chapter is the hypothesis proposing and research design, first from the perspective of corporate strategic deviance and risks, combined with the signal demand theory of accounting conservatism, put forward the research hypothesis of this paper, then from the sample selection and data sources, the selection of variables and definitions, and the design of the model to develop the study design. The fourth chapter is an empirical analysis. The fifth chapter is conclusion, suggestion and prospect.

The possible contributions of this article are: 1) Considering the influence of accounting conservatism from the perspective of corporate strategic deviance, it provides a new perspective for the research field between non-accounting information and accounting decision-making, and contributes a new influencing factor to the consequentiality of accounting conservatism. 2) The study of the consequences of corporate strategic deviance provides a new perspective on the degree to which the degree of deviation of the firm's conventional behavior from the industry affects its accounting choices. This effect is extremely important to the company's external stakeholders and can be applied to creditors, investors, and even regulators. 3) The state-owned enterprises and private enterprises respectively study the relationship between their corporate strategic deviance and accounting conservatism, and the conclusions obtained are helpful for understanding in depth the institutional differences between state-owned enterprises and private enterprises, thus giving corresponding suggestions for the reform of the ownership system of enterprises. 
And the main drawbacks of this article are: 1) The measurement of corporate strategic deviance is not perfect. Geletkanycz and Hambrick (1997) used the six indicators including capital intensity, degree of fixed asset renewal, period cost input, corporate financial leverage, $\mathrm{R} \& \mathrm{D}$ spending, and advertising investment to measure the strategic characteristics of a company, but due to the availability of data and the actual situation of Chinese enterprises, the data or disclosure of $\mathrm{R} \& \mathrm{D}$ expenditures and advertising investment is incomplete or the time of disclosure is too short. Therefore, when measuring the corporate strategy, this paper refers to Ye Kangtao's (2014) practice and uses net intangible assets replace $\mathrm{R} \& \mathrm{D}$ expenditures, sales expenses replace advertising expenditures. In the robustness test, we refer Tang et al.'s (2011) measure to exclude R \& D spending and advertising investment. 2) We apply the accrual cash flow model used by Ball and Shivakumar (2005) to measure the accounting conservatism. In the robustness test, a time series model of surplus was used. Actually there are many ways to measure accounting conservatism, we only select two of them.

\section{Definition of Concept and Literature Review}

\subsection{Definition of Corporate Strategic Deviance}

Meyer and Rowan proposed a formal organization framework in 1977. He believes that it is necessary to discuss an organization and make a clear distinction between formal organizational structure and daily work activities. The formal organizational structure is a blueprint for daily business activities. First, it includes the organizational structure: a series of offices, departments, positions, and processes; second, these elements are linked by clear goals and policies and a theory is constituted [1].

The formation of formal organizations is affected by two aspects. The first is based on the principle of rationality, also known as the universal theory [3]. The theory believes that a reasonable organizational structure should be able to effectively coordinate and control internal and external corporate networks, and effective organization. Structure is caused by market competition, because a more effective organizational structure can handle more complex problems and organizations can therefore survive in more complex environments.

But the theory has a premise that the organization will act in accordance with the pre-defined blueprint, and employees will coordinate and advance the work according to the preset procedures. However, the reality is not like this. Early scholars discovered that there is a huge gap between formal organizations and informal organizations [4]. Observations show that the relationships between employees in formal organizations are usually not very tight, and organizational elements, organizational elements and activities are usually loosely grouped together, employees often violate the rules, recommendations are not adopted, or face great uncertainty after adoption, and organizational activities therefore lack efficiency.

Therefore, an organization established by relying only on rational rules is un- 
stable and inefficient, because the above theory ignores another dimension in which organizational structures are formed: the legitimacy of organizations [1], and the existence of legitimacy is based on social rules. The theory discusses the evolution of the organizational structure on the premise of legitimacy. It holds that legitimacy is an endogenous variable of the organizational structure and remains unchanged. Therefore, its influence on the organizational structure is not discussed. However, in fact, social rules are indeed an important factor affecting the change of organizational structure.

Because organizations that are more in line with social norms will have higher legitimacy and are more likely to get more recognition from people in society. On the one hand, employees will have a higher sense of identity with the organization, and the efficiency of the enterprise will be higher. On the other hand, customers will also have more recognition of the company's products and services, corporate performance will be better. Therefore, companies that are more in line with social rules will have relatively good prospects for development in market competition [5].

While specific to an industry, each industry has its own unique basic rules and perceptions. These rules are more similar to creed-like existence and will be recognized by most participants in the industry. Under the shaping of these rules, the strategic choices in an industry will show certain similarities, because the implementation of the strategy that violates the basic rules will be eliminated by the market, thus demonstrating the similarity of the strategies. The above is the generation of strategic similarities, the opposite is strategic deviance [6]. The greater the difference in corporate strategy, the greater the risk the company faces, the greater the strategic deviance.

The corporate strategic deviance defined in this paper refers to the degree to which the resource allocation behavior of a company deviates from the average level of the industry. Specifically, we use the six indicators: capital intensity, renewed fixed assets, period cost input, corporate financial leverage, sales expense ratio, and intangible assets to measure the company's strategy, and then use industry standardization calculations to deviate from the industry, thus defining the company's strategic deviance.

\subsection{Definition of Accounting Conservatism}

The earliest definition of accounting conservatism was proposed by Bliss (1924), who believed that accounting conservatism was "confirmation of any expected loss, but did not confirm any expected return." [7] In 2005, Beaver and Ryan argued that conservatism refers to the underestimation of the book value to the market value of the company's net assets [8]. A later common definition was the conditional conservatism proposed by Basu (1997), that is, conservatism refers to the confirmation of good news (asset gains) that is more stringent than the confirmation of bad news (asset losses). The higher the asymmetry required when confirming between bad news and good news, the higher the conservatism [9]. 
In July 1989, the International Financial Accounting Standards Board (IASB) issued the "Framework for Preparing Financial Statements," which mentioned that the principle of conservatism means that in the face of uncertainty, it is necessary to be cautious when making estimates and not to falsely count assets or income, and does not falsely reduce liabilities or expenses. Conservatism has become a prudence in our country, and it is an important principle in China's corporate accounting. In December 1992, the old "Enterprise Accounting Standards" promulgated by the Ministry of Finance of the People's Republic of China used the principle of conservatism for the first time in corporate accounting. The regulations were formulated to reflect the provision for depreciation of assets for four assets including accounts receivable, inventory, short-term investments, and long-term investments. In January 1998, the Ministry of Finance promulgated the "Accounting System of the Limited Liability Company", further adjusted and improved conservatism from the following five aspects: cost and market price depreciation, accelerated depreciation, amortization of intangible assets, accounting treatment of investment, and recognition of income and investment income. 2006 the Ministry of Finance has promulgated the new "Enterprise Accounting Standards", which stipulates that when enterprises conduct accounting confirmation, measurement, and reporting of transactions and events, they should maintain due caution and should not overestimate assets or earnings, and underestimate liabilities, which can be said to be a clear definition of the principle of conservatism.

From the perspective of accounting standards, the purpose of financial reporting is to provide users with accounting information such as financial status, operating results, and cash flows of enterprises, and to reflect the performance of the company's management responsibilities, which helps users of financial reports to do economic decisions. The principle of conservatism is one of the requirements of the "trusted responsibility concept" in the purpose of financial reporting. In the modern enterprise management system, the company's ownership and management rights are separated, resulting in the concept of "entrusted responsibility concept". The owner of the enterprise as the entrusting party manages the enterprise for the enterprise's owner, and the enterprise's manager can independently make decisions after being entrusted. Due to the existence of principal-agent issues, external investors of the company need to obtain financial and accounting information of the enterprise and have high requirements for their reliability and authenticity. Under the current market economy conditions, the external environment is unpredictable and the competition is becoming fiercer. Changes in the external environment and the uncertainty of competition will have unpredictable effects on the company's operating activities. However, if companies use the accounting method based on the principle of conservatism, these uncertain factors can be reasonably estimated and judged. When the risks come, they can effectively cope with and prevent risks and do not cause large fluctuations. Such behavior is also a kind of self-protection for accountants (Li Zengquan, Lu Wenbin, 2003) [10]. At the same time, the im- 
plementation of the principle of conservertism in enterprises also helps protect the interests of owners and creditors, and to a certain extent is beneficial to the long-term development of the company.

Ball \& Shivakumar divided the principle of conservatism into conditional conservatism and unconditional conservatism [11]. Non-conditional conservatism is also known as ex ante conservatism and balance sheet conservatism. This conservative approach means that accounting methods are generally determined before the news arises and will not change due to changes in the operating environment. It was confirmed when assets and liabilities were formed, such as the use of the historical cost method, accelerated depreciation of fixed assets, and the use of expendable support for R \& D support. Conditional conservatism, also known as post-event conservatism or earnings conservatism, is an accounting treatment that responds to news when it appears, specifically to identify good news (asset gains) more stringent versus bad news (loss of assets). It also means that in the face of a bad business environment, the book value of assets will be impaired, but in a good business environment, asset impairment will not be transferred. Now academic research on non-conditional conservatism is less, and research on conditional conservatism is more, mainly because non-conditional conservatism is reflected in stock information, generally defined by accounting standards, and rule-oriented accounting standards will, to a certain extent, reduce the usefulness of accounting information and thus mislead decision makers who use accounting information to be judged; while conditional conservatism shows more of incremental information, which depends on management's judgment, which is a principle-oriented accounting principle, may cause relevant stakeholders to respond and cause changes in their behavior. It can also improve the validity of accounting information and has positive significance for corporate governance.

The accounting conservatism defined in this paper is conditional conservatism, and the measurement of conservatism is mainly based on the accrual cash flow model (ACF) used by Ball and Shivakumar (2005).

\subsection{Corporate Strategic Deviance Literature Review}

\subsubsection{Impact of Corporate Strategic Deviance on Business Performance} Geletkanycz and Hambrick (1997) found that the choice of corporate strategy is inseparable from the allocation of resources [5]. The implementation of corporate strategy relies on the allocation of resources. For enterprise which implements the conventional strategy in the industry, if the management of the enterprise has better industry relations, therefore the news and resources it brings can bring better performance for the company. On the contrary, for company which implements a major difference from the industry's conventional strategy, if the company's management has a better external relationship with the industry, therefore, the news and resources it brings can bring better performance to companies with greater strategic deviance. Hill and Hambrick (2005) studied the influence of CEO position on corporate strategy choices and corporate perfor- 
mance. The study found that those CEOs with higher self-assessment are more confident in their own judgment than systematic decisions and believe in their ability. Therefore, they have higher right to speak, their decisions are more personal and they may choose to deviate from the industry's conventional strategy. The effect is that the performance will be even more extreme [12]. Tang et al. (2011) examined the relationship between CEO rights, corporate strategic deviance, and corporate extreme performance. Studies have shown that CEOs with smaller power are often willing to follow industry norms and are therefore more likely to choose strategies that tend to be more conventional in the industry. The CEO, who leads the company to form its own corporate culture or corporate rules within the company, has a certain degree of substitution effect on the norms of the industry. Therefore, they are more likely to choose strategies that deviate from the industry's routine, and further bring extreme performance to the company. The rights of the board of directors will correspondingly weaken the relationship between CEO rights and corporate strategic deviance [13].

Zhao Feng et al. (2012) found that the diversification strategy of an enterprise can influence the performance of the enterprise through the interaction of dynamic capabilities, and the diversification strategy has a significant negative impact on the performance of the enterprise [14]. Chen Shou et al. (2014) took a sample of China's manufacturing listed companies to examine the relationship among CEO rights, corporate strategic deviance, and extreme performance. The study found that when the CEO's rights are relatively high, the board's and external parties' supervision are smaller, and the CEO can strengthen his position, use his position to promote the company's strategy to deviate from the industry's routines, bring greater risks to the company, and thus the company's performance may also deviate from the average. Further, the study found that the improvement of environmental dynamics can, to a certain extent, suppress the relationship between CEO rights and corporate strategic deviance [15]. Lei Hui et al. (2015) used the VAR model and impulse response function analysis methods to study the time lag of the enterprise's competitive strategy. The study found that the impact of the corporate competitive strategy on the performance of the company is lagging and persistent, while the performance of deviant strategy is more lagging behind and performance lasts longer [16].

\subsubsection{Corporate Strategic Deviance and Accounting Information Relevance}

Ye Kangtao et al. (2014) for the first time linked the difference between corporate strategy and the value of accounting information. He found that the greater the company's strategic deviance, the lower the value-related relevance of the income statement; and the greater the corporate strategic deviance, the higher the value-related relevance of owners' equity [17]. Ma Xiaomeng (2015) added the quality of information disclosure to the study of corporate strategic deviance and accounting correlations. He found that the greater the company's strategic deviance, the lower the value relevance of accounting earnings, and the higher 
the correlation of the value of net book assets. After further group regression, the author concluded that, for companies with very high disclosure quality, the degree of strategic deviance has no significant effect on the relationship between accounting surplus and book value of net assets. When the quality of information disclosure is poor, the degree of the company's strategic deviance will have a significant impact on the correlation between the value of accounting earnings and net book value [18].

\subsubsection{Corporate Strategic Deviance and Earnings Management}

Ye Kangtao et al. (2015) found that the degree of strategic deviance of an enterprise may affect earnings management. Specifically, the degree of corporate strategic deviance is positively related to the accounting accrued earnings management, and it is negatively related to the actual earnings management of the enterprise. Relationships, among which companies that have been audited by the "Big Four", will weaken the relationship between strategic deviance and accrued earnings management, indicating that the impact of strategic deviance on earnings management depends in part on the degree of information asymmetry [19]. Liu Xing (2016) studied the relationship between corporate strategy types and accounting earnings characteristics from the perspective of accounting conservatism. Studies have shown that exploratory firm conservatism will be lower, while defensive firms have higher levels of conservatism [20].

\subsection{Accounting Conservatism Literature Review}

The reason for conservatism can be traced back to the pay contract and debt contract that Watts proposed in 1993 [21]. Later in 2003, Watts further suggested that the cause of conservatism can be attributed to contractual restraints, shareholder litigation, taxes, and institutions [22].

\subsubsection{Contract Constraints}

The main reason for conservatism is contractual constraints. The point is that accounting conservatism is an effective tool for linking company organizations and external stakeholders, and can ease information asymmetry and rewards between companies and interest groups. Although contract and management are separated from financial statement information to some extent, accounting treatment in financial statements will give investors information on management performance, thus affecting investors' asset allocation and managers' compensation and benefits [22]. The explanation of contractual constraints also shows that accounting conservatism is beneficial to investors' information acquisition, so accounting conservatism has always been sought after by accounting standards makers and academia.

Ahmed et al. (2002) explained the causes of accounting conservatism from the two aspects of dividend distribution policy and debt contract in contractual constraints, and pointed out that companies with greater conflicts in dividend distribution policies have stronger accounting conservatism. To a certain extent, 
accounting conservatism can also reduce the cost of debt, which proves that accounting conservatism can effectively alleviate the contradiction between shareholders and creditors in the dividend distribution policy and reduce the company's debt cost [23]. Valeri V. Nikolaev's (2010) study further found that the specific terms of a contract in a public debt contract, such as restricting the transfer of decision making rights and control rights from shareholders to creditors when the company is in crisis, can make the company more inclined to timely confirm the loss, thus more conservative [24]. The studies of Liu Fengwei, Wang Yang (2006), Chen Xudong, and Huang Dengshi (2007) have shown that the level of corporate debt is directly proportional to the conservatism of accounting, that is, the higher the company debt, the more bank loans, the higher the degree of accounting conservatism [25] [26]. The study by Liu Yunguo et al. (2010) also showed that bank borrowings of different durations will have an impact on the firm's accounting conservatism [27].

In terms of corporate ownership structure and internal controls, LaFond (2005) explored the impact of ownership structure on accounting conservatism. The research found that companies with more concentrated equity have lower levels of accounting conservatism, while enterprises with decentralized ownership have higher accounting conservatism. This is because for companies with more concentrated equity, their private communication and exchange is the main mechanism of information transmission, which reduces the need for accounting information transmission, leads to lower accounting conservatism [28]. Cao Yu et al. (2005) also found that the stronger the shareholder's control over the listed company, the lower the accounting conservatism, and that when the chairman of the listed company is held by the chairman of the parent company, the accounting conservatism will perform even worse [29]. Fang Hongxing and Zhang Zhiping (2012) studied the impact of corporate internal control on accounting conservatism and found that companies with higher internal control quality also have higher accounting conservatism. When the quality of internal control is improved, accounting conservatism will be correspondingly improved [30].

In recent years, studies on the causes of accounting conservatism have mostly focused on the effect of management characteristics on accounting conservatism. Ahmed (2007) found that the more internal directors on the board, the lower the firm's accounting conservatism [31]. Lafond et al. (2008) discussed the relationship between management's ownership and accounting conservatism and found that the higher the management's rights, the lower the need for accounting conservatism [32]. The research of Zhang Zhaoguo et al. (2011) shows that the background characteristics of the management team have a certain influence on the accounting conservatism, which is reflected in the fact that the gender heterogeneity of the management team has no significant effect on the accounting conservatism. The age, education, and term heterogeneity of the management team will have an impact on accounting conservatism and the impact is positive. Further, the background characteristics of the chairman and 
chief financial officer also have an impact on accounting conservatism, similar to the characteristics of the management team [33]. Ahmed (2013) found that overconfidence managers overestimate future earnings, underestimate future risks, and lower the level of accounting conservatism [34]. Sun Guangguo and Zhao Jianyu (2014) also found that in China's listed companies, managers' overconfidence is negatively correlated with the level of corporate accounting conservatism [35].

In terms of the compensation contract, the research of Shen Yongjian et al. (2013) found that the different expectations of employees in the future regarding wages and wage rigidities will have an impact on the demand for accounting conservatism. Specifically, the higher of employee compensation and downward rigidity of wages will increase the conservatism of accounting [36].

\subsubsection{Shareholder Litigation}

Shareholders' litigation is another factor that affects the conservatism of accounting. Litigation will, to some extent, produce asymmetric returns: compared to underestimating net assets, overvaluation of net assets is more likely to result in litigation costs, that is, companies are more likely to be subject to shareholders' litigation when they overestimate their net assets, thereby increasing litigation costs. The accounting conservatism makes the enterprise tend to underestimate the net assets in the accounting treatment, which can effectively reduce the expected litigation costs. Watts (2003) suggested that corporate management is more likely to face the risk of shareholder litigation when overestimating net assets [22]. Kellogg (1984) found that in litigation faced by auditors, litigation caused by overvalued assets was 13 times lower than assets underestimated. Therefore, companies can reduce litigation risk through accounting conservatism [37]. Ball et al. (2003) sampled companies in four countries and regions in Southeast Asia (Thailand, Malaysia, Singapore, and Hong Kong) and found that all four countries lacked the need for accounting conservatism. One reason is that these four countries are facing less stressful legal proceedings [38].

\subsubsection{Tax Factors}

The impact of tax factors on accounting conservatism is mainly reflected in the fact that the asymmetry in the recognition of gains and losses makes managers of profit-oriented companies tend to reduce the present value of taxes, and the characteristics of accounting conservatism that extends the recognition of income and accelerating the recognition of fees extend the payment of taxes. There are few research results in this area.

Zhou Zehui (2012) examined the effect of the effective tax rate on accounting conservatism and found that there was a positive correlation between the two [39]. Che Fei (2012), based on China's 2008 corporate income tax reform, empirically examines the relationship between income tax reforms, accounting-tax differences, and accounting conservatism. Research shows that the closer the relationship between accounting and taxation, the stronger the accounting conservatism [40]. 


\subsubsection{Institutional Factors}

Finally, accounting standards makers and regulators also have the purpose of enhancing accounting conservatism. They are analogous to the asymmetries caused by litigation costs, as well as asymmetrical supervision costs. If companies often overestimate net assets, rather than underestimate net assets, accounting standards makers and regulators will be fooled and may make mistakes in decision-making. Therefore, accounting conservatism helps accounting standards-makers and regulators to reduce regulatory costs.

In terms of political connections, Zhu Fujien and Li Zhiwen (2008) found that state-controlled companies will lead to governance issues such as corporate insider control, soft debt constraints, and government intervention, so that state-owned enterprises will have lower accounting conservatism [41]. The study of Du Xingqiang et al. (2009) found that if there are any forms of political ties in listed private companies in China, the level of accounting conservatism will be reduced accordingly [42]. Chen Yanyan et al. (2013) found that this relationship exists in all listed companies [43]. Jiang Yan and Tian Kunru (2013) found that as a means of government macro-control, government subsidies will reduce the conservatism of state-owned holding companies [44].

\subsection{Literature Commentary}

Judging from the impact of corporate strategic deviance, foreign literature mainly relates corporate strategic deviance to the characteristics of management, and then studies its impact on corporate extreme performance, or discusses the causes and consequences of corporate strategic deviance using theoretical models. However, domestic research on the relationship between corporate strategic deviance and accounting information or decision-making has only started since Ye Kangtao (2014), only in recent years, it has attracted many scholars to study, mainly focusing on the company's strategic deviance on the company's extreme performance, accounting information value, earnings management and other aspects. In addition, the existing literature does not have links to corporate strategic deviance and accounting conservatism.

Judging from the reasons for the conservatism of accounting, research at home and abroad has matured, mainly starting from the four aspects proposed by Watts (2003) (contract factors, shareholder lawsuits, taxation, and institution) [22]. In recent years, the influencing factors of accounting conservatism mainly focused on the influence of management characteristics on accounting conservatism, and the accounting institution and supervision features were also involved.

This paper studies the influence of corporate strategic deviance on accounting conservatism, and in fact focuses on the impact of non-accounting information (strategic choices) on corporate accounting behavior (accounting conservatism). Similarly, Liu Xing (2016) examined the impact of corporate strategy types on accounting conservatism [20], but this article is measured from the perspective of corporate strategic deviance, taking into account the factors that an industry 
deviates from the industry center strategy in the development process. Furthermore, in the part of the definition of the concept of corporate strategic deviance, the theoretical basis for the emergence of corporate strategic deviance are reviewed, compared with the existing research on corporate strategic deviance has a more theoretical basis.

\section{Assumptions and Research Design}

\subsection{Assumptions}

\subsubsection{Corporate Strategic Deviance and Risks}

Meyer and Rowan (1977) believed that each industry has its own unique basic rules and perceptions. These rules are similar to the existence of creeds and will be recognized by most participants in the industry [1]. Under the shaping of these rules, the strategic choices in an industry will show certain similarities, because the implementation of the strategy that violates the basic rules may be eliminated by the market, so that most companies in an industry will show a strategy similarity in order to avoid risks. The opposite is that some companies choose not to follow the basic rules in the industry. Their strategic choices are different from the strategies commonly implemented in the industry.

Specifically, Meyer and Rowan (1977) argued from the perspective of legitimacy that those companies with deviant strategy will face greater risks because they reject the consensus that is generally accepted in the industry, while differentiated companies weaken their ability to acquire resources in the industry and potential trading partners, such as customers, suppliers, etc., embodied in three aspects: first, a potential resource exchange may not understand the deviant corporate strategy, therefore, it may limit the supply of resources; second, trading partners will set lower-required trading terms for compliance companies because the potential risks to these enterprises may be lower, compared to those of the companies that are subject to deviance; finally, companies that choose a deviant strategy are also more likely to go bankrupt, and are therefore more likely to be unapproved by the counterparty [1].

The degree of corporate strategic deviance may also affect the firm's risk path as follows: for example, companies that adopt industry-standard strategies may be more in line with regulatory and legal requirements and can reduce litigation risks accordingly with the support of the government, it will enhance the stability of the company's future development and effectively reduce risks; second, companies that adopt industry-standard strategies tend to be close to the opinions of experts in the industry, while those companies which strategies different from the industry are likely to be untested and have greater uncertainty, and may increase the risk of the company; finally, Geletkanycz and Hambrick (1997) showed that adopting industry-standard strategies can save the cost of finding other deviant strategies and help reduce decision-making costs and decision-making risks [5].

In summary, the deviance of corporate strategies will increase the risks faced by companies. 


\subsubsection{Signal Demand Theory of Accounting Conservatism}

Lin's (2006) study considers accounting discretion and conservatism as two distinctive features of financial statements [45]. On the other hand, if we do not consider the impact on the future, then we cannot have a good understanding of accounting conservatism. He established a two-stage model that took into account the future impact on the present and put forward a signal hypothesis of the need for accounting conservatism. The background of the model is as follows: The client gives the agent a project, which is conducted in two phases, at the same time, the project is divided into "good project" and "bad project". After the contract is signed, the degree of effort of the agent is unobservable, but the agent can know the good or bad information of his project and also has the accounting discretion. It can choose conservative depreciation method to underestimate current net assets and net income, or choose aggressive depreciation method to overestimate current net assets and net income. Although the project has a self-reporting mechanism (the agent can report privately to the principal), this is usually not trustworthy. In this case, the different depreciation methods selected by the agent for the project can be used as information transfer channel between the principal and the agent. The experimental results show that those agents who are assigned to "good projects" will choose a more conservative depreciation method. The purpose is to win higher compensation in the second period at the expense of the compensation in the first period because the prospect of the project is predictable, and good. Such behavior is optimal for agents who have "good projects". But for agents assigned to "bad projects", the same choice is not optimal for them because the project's prospects are not good, if they adopt a conservative depreciation policy and sacrifice the first period compensation, the second phase of the remuneration is likely to make up for the loss of the first period, in this case, those agents who have "bad items" still choose a conservative depreciation policy, the purpose is to convey to the client a signal that the project's prospects are good, but the rewards for choosing such an approach will not necessarily outweigh the immediate benefits of directly using non-conservative depreciation policies.

The signal hypothesis of Wang et al. (2009) is based on the asymmetric information debt market [46]. Stiglitz \& Weiss (1981) pioneered the issue of adverse selection and signaling issues based on the debt market. The study found that when there is serious information asymmetry in the debt market, banks cannot identify companies with higher risks and companies with lower risks. In this case, the bank will implement a credit allocation system, so that the demand for and supply of loans can be cleared out in an unbalanced situation [47]. After Stiglitz \& Weiss, many scholars, on the basis of studying adverse selection and signal problems, are committed to proposing a solution to the credit system of credit supply. Wang et al. (2009) hypothesis of conservative signal demand is based on this. Research shows that accounting conservatism can be used as an information transfer means (signal) of debtor and creditor, and often before the signing of a debt contract, accounting conservatism can transfer relevant infor- 
mation privately to creditors, thereby reducing information asymmetry in the debt market. This will benefit both the lender and the borrower. They constructed a conservative-signal model with a dominant segregated equilibrium in which lower-risk companies choose higher accounting conservatism, while higher-risk companies choose lower-level accounting conservatism [46].

The signal hypothesis of the accounting conservatism demand of Lin (2006) and Wang et al. (2009) separately examined the signal function of accounting conservatism after performing post- and ex-ante perspectives [45] [46]. Lin (2006) examines the role of accounting conservatism as a medium of communication between principals and agents, reducing the asymmetry of information afterwards, and belongs to the moral hazard model; while Wang et al. (2009) examine the role of accounting conservatism as a conduit between debtors and creditors and reduce the asymmetry of information in advance, which is an adverse selection model.

In general, accounting conservatism, as a means of signal transmission, will play a greater role if the company is faced with less risk. Conversely, if the enterprise is exposed to a relatively high risk, the accounting conservatism may be lower.

\subsubsection{Assumptions}

Meyer and Rowan (1977) proposed that companies will choose to converge with the industry due to the factors of legality [1], and then choose the industry's conventional strategy, and those companies that differ greatly from the industry's conventional strategies will have greater business risks due to increased litigation risks, higher decision-making costs, and reduced access to information resources in the industry. From the point of view of signal demand theory for accounting conservatism, Lin (2006) showed that, compared with conservative post-event information transfer, it is not optimal for companies with greater operating risks to choose a more conservative accounting policy [45]; while Wang (2009) showed that, due to adverse selection factors, the dominant result of the balance between conservatism and signal transmission is that companies with higher risks will choose lower accounting conservatism [46]. That is, the greater the degree of deviance of the company's strategy, the greater the risk the company faces, and the more likely the firm will choose a lower level of conservatism.

From the perspective of the performance of corporate accounting information, the greater the degree of strategic deviance of the company, the greater the operational uncertainty the company will face in the future. Exhibited in accounting information processing methods, the accounting information of such companies will also have greater uncertainty, reducing the reliability of company's forecast of future operating conditions and profitability, thus reducing the level of accounting conservatism.

Comprehensive theoretical research and domestic and foreign literature, put forward the hypothesis of this paper as follows: 
Hypothesis I: The greater the deviance in corporate strategy, the lower the accounting conservatism.

In China, state-owned and private enterprises have essential differences in strategic deployment, business management. Specifically, the strategic business objectives of state-owned enterprises are not merely for the purpose of making profits, there are often many political connections in the process of strategic implementation and management, and due to their special entrusted agency system (the officials are the first agents, the remaining shareholders are scattered), making state-owned listed companies often present with different governance issues, such as internal controller problems, soft debt constraints, government intervention, and policy protection. A large number of studies have found that the strategic positioning of state-owned enterprises and private enterprises is different, making the transparency of accounting information lower. This paper intends to classify the sample by the nature of property rights and study the effect of deviant strategy on accounting conservatism in state-owned and private enterprises.

Hypothesis II: In private listed companies, the relationship between corporate strategic deviance and accounting conservatism is more significant.

\subsection{Sample Selection and Data Sources}

This article takes a sample of China's A-share listed companies from 2000 to 2016, which excludes ST, ${ }^{\star}$ ST companies, and financial and insurance companies, and eliminates missing samples of data. A total of 17,024 samples were obtained. The company's required strategic deviance measure and accounting conservatism measure are all from the Csmar database. Data analysis and regression use Excel and Stata measurement software.

\subsection{Selection and Definition of Variables}

\subsubsection{Measurement of Corporate Strategic Deviance}

The strategic deviances of enterprises are finally reflected in the differences in the resource allocation structure of enterprises (Mintzberg, 1978) [48]. The measurement of corporate strategic deviance mainly draws on the research of Geletkanycz and Hambrick (1997), and uses the following six indicators as the characteristics of the company's strategy: capital intensity, renewed fixed assets, period cost input, corporate financial leverage, advertising investment, and R \& D expenditures [5]. However, due to the inaccessibility of corporate advertising costs and R \& D expenditure data, Tang (2011) selected the first four indicators, standardized them according to the industry, and then summed up the absolute values of the four indicators as a difference in corporate strategy [13]. According to China's actual situation, Ye Kangtao et al. $(2014,2015)$ used sales expenses instead of advertising expenses, and used net value of intangible assets to represent R \& D expenditures [17] [19]. Table 1 shows the six indicators which were used as a measure of corporate strategy to further measure the company's strategic deviance: 
Table 1. Corporate strategy indicators.

\begin{tabular}{ccc}
\hline Number & Indications & Formulas \\
\hline 1 & Capital intensity & Fixed assets/employees \\
2 & Renewed fixed assets & Net fixed assets/original value of fixed assets \\
3 & Period cost input & Management fee/operating income \\
4 & Corporate & (Short-term loans + long-term loans + bonds payable)/net assets \\
5 & Sinancial leverage & \\
6 & Intangible assets ratio & Sales expenses/operating income \\
\hline
\end{tabular}

This article mainly uses Ye Kangtao's $(2014,2015)$ measurement of corporate strategic deviance, using the above six indicators to measure corporate strategy, and then proceed with the following: First, standardize these indicators according to the year and industry, that is, each indicator minus its annual industry average divided by its annual industry standard deviation, and then take the absolute value, thus get each company's deviation from the average level of the industry in each strategic dimension; secondly, after summarizing the indicators standardized by each company, and then averaging them to obtain the strategic deviance index SD, the larger the index, the bigger the difference in resource allocation structure between the company and other companies in the same industry in the same year, the greater the strategic deviance [17] [19].

\subsubsection{Measures of Accounting Conservatism}

Due to the special background of China's shareholding reform and the uniqueness of the stock market system, the share price of listed companies in China does not respond well to the company's "good news" and "bad news" (Yang Huajun, 2007) [49]. Therefore, this paper mainly uses the accrued cash flow model (ACF) of Ball and Shivakumar (2005) to measure the accounting conservatism [11]. Ball and Shivakumar (2005) believe that the randomness of an accrued item will result in cash flow of two different time series features, namely negatively correlated cash flow in time series and positively correlated cash flow. This is because a year's cash outflow does not mean a reduction in the value of the company. In the future, it will bring more cash flow. The negative-related cash flow will make the cash flow contain more noise. For this type of cash flow, the role of accounting accruals is to reduce the noise in cash flow from operating activities. Ball and Shivakumar (2005) used cash flow from operating activities as an alternative variable to "good news" and "bad news" to propose an accrual-cash flow model. The main model is (Model 1):

$$
\mathrm{ACC}_{i, t}=\beta_{0}+\beta_{1} \mathrm{CFO}_{i, t}+\beta_{2} \mathrm{DCFO}_{i, t}+\beta_{3} \mathrm{CFO}_{i, t} \times \mathrm{DCFO}_{i, t}+\varepsilon_{i, t}
$$

Among them, ACC equals accrued profit for the current period divided by the total assets at the beginning of the period, and accrued profit equals the current 
operating profit minus the cash flow of operating activities during the period; CFO equals cash flow from operating activities for the current period divided by total assets at the beginning of the period, cash flow from operating activities equals current operating profit for the period plus depreciation for the current period, minus the increase in working capital for the period, and the increase in working capital equals the increase in current assets for the current period, minus increase in cash, minus the increase in current liabilities for the period, then add the amount of long-term debt due within one year of the current period; DCFO is a dummy variable, if CFO is less than 0 , DCFO is equal to 1 , otherwise it is 0 . In the above model, the relationship between the metric accrual project and the positive operating cash flow, $\beta_{1}$, and the relationship between the metric accrual project and the negative operating cash flow $\left(\beta_{2}+\beta_{3}\right)$ should be negative. As the accrued project has the effect of mitigating the noise from operating cash flow and confirming the economic profit and loss in a timely manner, the correlation between the accrual project and negative operating cash flow should be stronger. $\mathrm{CFO} \times \mathrm{DCFO}$ represents the asymmetry confirmation of good news and bad news. It measures the conservatism of accounting. If the sign of $\beta_{3}$ is positive, it indicates the existence of accounting conservatism.

\subsubsection{Selection of Control Variables}

According to the previous studies on the conservatism of corporate accounting, when examining the conservatism of corporate accounting, the size, debt-to-asset ratio, and market-to-book ratio of firms will significantly affect the conservatism of accounting. At the same time, there are also large differences in the accounting conservatism in different industries and years. This article mainly selects the enterprise size (SIZE), the corporate asset-liability ratio (LEV) and the company's market-book ratio (MTB) as the control variables of this regression model, and controls the year and industry variables in the main regression.

\subsection{Model Design}

To test Hypothesis I, this paper adds the measurement index SD of the company's strategic deviance on the basis of the ACF model, selects the company size (SIZE), the asset-liability ratio (LEV), the market-book ratio (MTB) as control variables, and builds the following model (Model 2):

$$
\begin{aligned}
\mathrm{ACC}= & \beta_{0}+\beta_{1} \mathrm{CFO}+\beta_{2} \mathrm{DCFO}+\beta_{3} \mathrm{CFO} \times \mathrm{DCFO}+\beta_{4} \mathrm{SD}+\beta_{5} \mathrm{SD} \times \mathrm{CFO} \\
& +\beta_{6} \mathrm{SD} \times \mathrm{DCFO}+\beta_{7} \mathrm{SD} \times \mathrm{CFO} \times \mathrm{DCFO}+\beta_{8} \mathrm{SIZE}+\beta_{9} \mathrm{SIZE} \times \mathrm{CFO} \\
& +\beta_{10} \mathrm{SIZE} \times \mathrm{DCFO}+\beta_{11} \mathrm{SIZE} \times \mathrm{CFO} \times \mathrm{DCFO}+\beta_{12} \mathrm{LEV}+\beta_{13} \mathrm{LEV} \\
& \times \mathrm{CFO}+\beta_{14} \mathrm{LEV} \times \mathrm{DCFO}+\beta_{15} \mathrm{LEV} \times \mathrm{CFO} \times \mathrm{DCFO}+\beta_{16} \mathrm{MTB} \\
& +\beta_{17} \mathrm{MTB} \times \mathrm{CFO}+\beta_{18} \mathrm{MTB} \times \mathrm{DCFO}+\beta_{19} \mathrm{MTB} \times \mathrm{CFO} \times \mathrm{DCFO}+\varepsilon_{i, t}
\end{aligned}
$$

Among them, $\beta_{7}$ measures the effect of corporate strategic deviance on accounting conservatism. If $\beta_{7}<0$, it indicates that the greater the company's strategic deviance, the lower the accounting conservatism.

Table 2 shows the definition of the main variable. 
Table 2. Definition of major variables.

\begin{tabular}{|c|c|c|}
\hline Variable name & $\begin{array}{l}\text { Variable } \\
\text { code }\end{array}$ & Variable description \\
\hline Accrued profit & ACC & $\begin{array}{c}\text { Accrued profit }=\text { (operating profit operating activity cash flow }) / \\
\text { total assets at the beginning of the period }\end{array}$ \\
\hline $\begin{array}{l}\text { Cash flow from } \\
\text { operating activities }\end{array}$ & $\mathrm{CFO}$ & $\begin{array}{c}\text { Cash flow from operating activities }=\text { operating profit } \\
+ \text { depreciation }- \text { working capital } \\
\Delta \text { working capital }=\Delta \text { current liabilities }-\Delta \text { cash } \\
-\Delta \text { current liabilities }+\Delta \text { long-term liabilities due within one year }\end{array}$ \\
\hline $\begin{array}{l}\text { Operating } \\
\text { activity cash flow }\end{array}$ & DCFO & $\begin{array}{l}\text { When the operating activity cash flow } \\
\text { is less than } 0 \text {, the value is } 1 \text {; otherwise it is } 0\end{array}$ \\
\hline Capital intensity & S1 & Fixed assets/employees \\
\hline Renewed fixed assets & S2 & Net fixed assets/original value of fixed assets \\
\hline Period cost input & S3 & Management fee/operating income \\
\hline $\begin{array}{l}\text { Corporate } \\
\text { financial leverage, }\end{array}$ & S4 & (Short-term loans + long-term loans + bonds payable)/net assets \\
\hline Sales expense ratio & S5 & Sales expenses/operating income \\
\hline $\begin{array}{l}\text { Intangible } \\
\text { assets ratio }\end{array}$ & S6 & Intangible assets/operating income \\
\hline $\begin{array}{l}\text { Corporate } \\
\text { strategic deviance }\end{array}$ & SD & $\begin{array}{l}\text { S1-S6 are summed after industry standardization, } \\
\text { absolute value is calculated, and finally averaged }\end{array}$ \\
\hline Enterprise size & SIZE & Enterprise size $=$ the natural logarithm of the company's total assets \\
\hline Asset-liability ratio & LEV & Asset-liability ratio $=$ total liabilities/total assets \\
\hline Market book ratio & MTB & Market book ratio = equity market value/book value of equity \\
\hline
\end{tabular}

\subsection{Descriptive Statistics}

From Table 3, we can see that the maximum value of the company's strategic deviance (SD) is 348.8395 , the minimum value is 0.0445 , the average value is 0.7350 , and the standard deviation is 3.4576 , which indicates that the overall fluctuation range is large, and there is a large difference between the samples. The average value of enterprise accruals (ACC) is -0.0472 , and the standard deviation is 0.8715 , which shows that the distribution is relatively uniform. The minimum value of cash flow from operating activities was -12.9909 , the maximum was 111.5884 , the average was 0.0889 , the standard deviation was 0.9343 , and the distribution difference was also large, but the fluctuation range was not significant. There is no significant difference between the maximum value of the enterprise size (SIZE) of 28.5367 and the minimum value of 17.0825 , and the average value and the median value are also similar, indicating that the size of the sample companies is relatively even. The maximum value of the asset-liability ratio (LEV) is 13.7114 , and the minimum value is 0.0330 . The difference between the median and the average is small, and the standard deviation is relatively low (0.3476), which indicates that the overall distribution of asset-liability ratios of the sample companies is relatively average, but there is a big difference between the maximum and minimum values. The maximum value of 
Table 3. Descriptive statistics.

\begin{tabular}{ccccccc}
\hline Variable name & Number of samples & Mean & Max & Min & Median & SD \\
\hline SD & 17024 & 0.7350 & 348.8395 & 0.0445 & 0.4931 & 3.4576 \\
ACC & 17024 & -0.0472 & 14.3581 & $-1.1 \mathrm{e}+02$ & -0.0318 & 0.8715 \\
CFO & 17024 & 0.0889 & 111.5884 & -12.9909 & 0.0685 & 0.9343 \\
DCFO & 17024 & 0.2592 & 1.0000 & 0.0000 & 0.0000 & 0.4382 \\
SIZE & 17024 & 21.8632 & 28.5087 & 17.0825 & 21.6933 & 1.2904 \\
LEV & 17024 & 0.5270 & 13.7114 & 0.0330 & 0.5146 & 0.3476 \\
MTB & 17024 & 1.7358 & 33.3767 & 0.0542 & 1.2738 & 1.6760 \\
\hline
\end{tabular}

the company's market-book ratio (MTB) is 33.3767, the minimum value is 0.0542 , and the difference between the maximum and minimum values is relatively large, the average value is 1.7358 , the median is 1.2738 , and the standard deviation is 1.6760 , indicating that the sample company's market-book ratio distribution is not uniform.

\section{Empirical Analysis}

\subsection{Correlation Analysis}

From Table 4, it can be seen that corporate accruals have a significant negative correlation with cash flow from operating activities, while corporate strategic deviance have no correlation with accrued profits. Firm size and financial leverage are negatively correlated with accrued profits, the book-to-book ratio is positively related to accruals.

\subsection{Analysis of Regression Results}

\subsubsection{Main Regression Analysis}

Table 5 reports the regression results (Model 2) of the test results of accounting conservatism (Model 1) and the relationship between firm strategic differences and accounting conservatism. Among them, the test result of Model 1 (Accrual Cash Flow Model) is in the second column. We expect the sign of the CFO to be negative and the test result to be negative $\left(\beta_{1}=-0.9230, t=-36.81\right)$. There is a significant negative correlation between flows and accruals; at the same time, the coefficient of $\mathrm{CFO}{ }^{*} \mathrm{DCFO}$ is negative $\left(\beta_{3}=-0.1690, t=-4.76\right)$, indicating that the sample company's accounting conservatism is low.

The test result of model 2 (main regression model) is in the third column. We expect that the coefficient of $\mathrm{SD}{ }^{\star} \mathrm{CFO}{ }^{*} \mathrm{DCFO}$ is negative, and the test result is in line with expectations $\left(\beta_{7}=-0.0319, t=-8.18\right)$, indicating that there is a significant negative correlation between the company's strategic deviance and accounting conservatism, the greater the difference in corporate strategy, the lower the accounting conservatism. Furthermore, the coefficient of SIZE * CFO * DCFO is positive $\left(\beta_{11}=0.0083, t=2.37\right)$, indicating that the firm size is positively related to accounting conservatism. The coefficient of $\mathrm{LEV}{ }^{\star} \mathrm{CFO}{ }^{\star} \mathrm{DCFO}$ is 
Table 4. Correlation analysis.

\begin{tabular}{cccccccc}
\hline & ACC & CFO & DCFO & SD & SIZE & LEV & MTB \\
\hline ACC & 1.0000 & & & & & & \\
CFO & $-0.9914^{*}$ & 1.0000 & & & & & \\
DCFO & $0.1088^{*}$ & $-0.1242^{*}$ & 1.0000 & & & & \\
SD & -0.0013 & -0.0044 & $0.0361^{\star}$ & 1.0000 & & & \\
SIZE & $-0.0192^{*}$ & $0.0357^{*}$ & $-0.0971^{*}$ & $-0.0363^{*}$ & 1.0000 & & \\
LEV & $-0.0178^{*}$ & $-0.0161^{*}$ & $0.0790^{*}$ & $0.0760^{*}$ & $0.0524^{*}$ & 1.0000 & \\
MTB & $0.0234^{*}$ & -0.0095 & $0.0231^{\star}$ & $0.0232^{\star}$ & $-0.3683^{*}$ & $-0.0596^{*}$ & 1.0000 \\
\hline
\end{tabular}

Notes: $t$ statistics in parentheses, ${ }^{*} \mathrm{p}<0.10,{ }^{* *} \mathrm{p}<0.05,{ }^{* * *} \mathrm{p}<0.01$.

Table 5. Master regression results.

\begin{tabular}{|c|c|c|}
\hline Variables & Model 1 ACC & Model 2 ACC \\
\hline \multirow[t]{2}{*}{$\mathrm{CFO}$} & $-0.9230^{* * *}$ & $-0.3184^{* * *}$ \\
\hline & $(-36.81)$ & $(-6.12)$ \\
\hline \multirow[t]{2}{*}{ DCFO } & $-0.0462^{\star * *}$ & $-0.1962^{* * *}$ \\
\hline & $(-10.69)$ & $(-6.06)$ \\
\hline \multirow[t]{2}{*}{$\mathrm{CFO} * \mathrm{DCFO}$} & $-0.1690^{* * *}$ & $-0.8556^{* * *}$ \\
\hline & $(-4.76)$ & $(-9.79)$ \\
\hline \multirow[t]{2}{*}{ SD } & & $-0.0055^{* * *}$ \\
\hline & & $(-10.65)$ \\
\hline \multirow[t]{2}{*}{$\mathrm{SD}^{*} \mathrm{CFO}$} & & $0.0279^{\star * *}$ \\
\hline & & $(15.37)$ \\
\hline \multirow[t]{2}{*}{$\mathrm{SD} * \mathrm{DCFO}$} & & $0.0040^{\star * *}$ \\
\hline & & $(4.89)$ \\
\hline \multirow[t]{2}{*}{$\mathrm{SD} * \mathrm{CFO} * \mathrm{DCFO}$} & & $-0.0319^{* * *}$ \\
\hline & & $(-8.18)$ \\
\hline \multirow[t]{2}{*}{ SIZE } & & $0.0171^{\star * *}$ \\
\hline & & $(19.82)$ \\
\hline \multirow[t]{2}{*}{$\mathrm{SIZE}^{*} \mathrm{CFO}$} & & $-0.0053^{*}$ \\
\hline & & $(-2.40)$ \\
\hline \multirow[t]{2}{*}{$\mathrm{SIZE}^{*} \mathrm{DCFO}$} & & $0.0090^{\star * *}$ \\
\hline & & $(6.21)$ \\
\hline \multirow[t]{2}{*}{$\mathrm{SIZE}^{*} \mathrm{CFO}{ }^{*} \mathrm{DCFO}$} & & $0.0083^{*}$ \\
\hline & & $(2.37)$ \\
\hline \multirow[t]{2}{*}{ LEV } & & $-0.0585^{\star * *}$ \\
\hline & & $(-11.98)$ \\
\hline \multirow[t]{2}{*}{$\mathrm{LEV} * \mathrm{CFO}$} & & $-0.7399^{* * *}$ \\
\hline & & $(-30.99)$ \\
\hline
\end{tabular}




\begin{tabular}{|c|c|c|}
\hline Continued & & \\
\hline $\mathrm{LEV}^{*} \mathrm{DCFO}$ & & $\begin{array}{c}-0.0371^{* * *} \\
(-6.44)\end{array}$ \\
\hline $\mathrm{LEV}^{*} \mathrm{CFO} * \mathrm{DCFO}$ & & $\begin{array}{c}0.6984^{* * *} \\
(28.94)\end{array}$ \\
\hline MTB & & $\begin{array}{c}0.0023^{* * *} \\
(3.29)\end{array}$ \\
\hline $\mathrm{MTB} * \mathrm{CFO}$ & & $\begin{array}{c}0.0533^{* * *} \\
(27.56)\end{array}$ \\
\hline $\mathrm{MTB}{ }^{\star} \mathrm{DCFO}$ & & $\begin{array}{c}0.0075^{* * *} \\
(6.27)\end{array}$ \\
\hline $\mathrm{MTB}^{*} \mathrm{CFO}{ }^{\star} \mathrm{DCFO}$ & & $\begin{array}{c}-0.0296^{* * *} \\
(-6.70)\end{array}$ \\
\hline Constant & $\begin{array}{c}0.0420^{\star * *} \\
(11.950)\end{array}$ & $\begin{array}{r}-0.3651^{\star * \star} \\
(-5.627)\end{array}$ \\
\hline Year & YES & YES \\
\hline Industry & YES & YES \\
\hline Observations & 17024 & 17024 \\
\hline R-squared & 0.984 & 0.990 \\
\hline Adjust_R ${ }^{2}$ & 0.984 & 0.989 \\
\hline
\end{tabular}

Notes: $t$ statistics in parentheses, ${ }^{*} \mathrm{p}<0.10,{ }^{* *} \mathrm{p}<0.05,{ }^{* * *} \mathrm{p}<0.01$.

significantly positive $\left(\beta_{15}=0.6984, t=28.94\right)$, indicating that the company's asset-liability ratio is positively correlated with the accounting conservatism. The higher the enterprise's financial leverage, the stronger the accounting conservatism. The coefficient of MTB ${ }^{*} \mathrm{CFO} * \mathrm{DCFO}$ was significantly negative $\left(\beta_{19}=\right.$ $-0.0296, t=-6.70)$, indicating that the company's market-book ratio was negatively correlated with accounting conservatism.

\subsubsection{Analysis of Group Regression Results}

Table 6 is based on the empirical results of the classification test on the nature of corporate property rights. The second column is the use of samples of state-owned enterprises to examine the impact of corporate strategic deviance on accounting conservatism. Among them, the coefficient of $\mathrm{SD}{ }^{*} \mathrm{CFO}{ }^{*} \mathrm{DCFO}$ is not significant $\left(\beta_{7}=-0.0071, t=-0.25\right)$, which shows that in the state-owned enterprises, the strategic deviance among the companies are difficult to affect the conservatism of accounting. It may be due to the fact that the special governance system of state-owned enterprises leads to the unsmooth transmission of corporate strategic information to accounting information. The third column uses a sample of private enterprises to examine the effect of corporate strategic deviance on accounting conservatism, where the $\mathrm{SD}{ }^{\star} \mathrm{CFO}{ }^{*} \mathrm{DCFO}$ coefficient is 
Table 6. Grouping regression results.

\begin{tabular}{|c|c|c|}
\hline Variables & State-owned enterprises ACC & Private enterprise ACC \\
\hline \multirow[t]{2}{*}{$\mathrm{CFO}$} & $-0.8551^{\star * \star}$ & -2.3178 \\
\hline & $(-5.71)$ & $(-1.42)$ \\
\hline \multirow[t]{2}{*}{ DCFO } & $-0.1272^{\star * *}$ & -0.3141 \\
\hline & $(-3.07)$ & $(-1.35)$ \\
\hline \multirow[t]{2}{*}{$\mathrm{CFO} * \mathrm{DCFO}$} & 0.1548 & $2.9602^{*}$ \\
\hline & $(0.50)$ & $(1.75)$ \\
\hline \multirow[t]{2}{*}{ SD } & -0.0004 & $-0.0222^{\star \star}$ \\
\hline & $(-0.24)$ & $(-2.50)$ \\
\hline \multirow[t]{2}{*}{$\mathrm{SD} * \mathrm{CFO}$} & -0.0221 & $0.1392^{* *}$ \\
\hline & $(-1.41)$ & $(2.47)$ \\
\hline \multirow[t]{2}{*}{$\mathrm{SD} * \mathrm{DCFO}$} & -0.0055 & 0.0110 \\
\hline & $(-1.11)$ & $(1.17)$ \\
\hline \multirow[t]{2}{*}{$\mathrm{SD} * \mathrm{CFO} * \mathrm{DCFO}$} & -0.0071 & $-0.1482^{\star * *}$ \\
\hline & $(-0.25)$ & $(-2.61)$ \\
\hline \multirow[t]{2}{*}{ SIZE } & $0.0157^{\star * *}$ & 0.0122 \\
\hline & $(12.90)$ & $(1.28)$ \\
\hline \multirow[t]{2}{*}{$\mathrm{SIZE}^{*} \mathrm{CFO}$} & $0.0130^{*}$ & 0.0767 \\
\hline & $(1.77)$ & $(1.05)$ \\
\hline \multirow[t]{2}{*}{$\mathrm{SIZE}^{*} \mathrm{DCFO}$} & $0.0086^{* * *}$ & 0.0130 \\
\hline & $(3.79)$ & $(1.26)$ \\
\hline \multirow[t]{2}{*}{$\mathrm{SIZE}^{*} \mathrm{CFO} * \mathrm{DCFO}$} & $-0.0342^{\star * *}$ & $-0.1581^{\star *}$ \\
\hline & $(-2.75)$ & $(-2.10)$ \\
\hline \multirow[t]{2}{*}{ LEV } & $-0.0824^{\star * \star}$ & -0.0417 \\
\hline & $(-8.26)$ & $(-1.25)$ \\
\hline \multirow[t]{2}{*}{$\mathrm{LEV} * \mathrm{CFO}$} & $-0.4978^{\star * *}$ & $-0.7634^{\star * *}$ \\
\hline & $(-6.66)$ & $(-3.37)$ \\
\hline \multirow[t]{2}{*}{$\mathrm{LEV}^{*} \mathrm{DCFO}$} & $-0.0801^{\star * *}$ & -0.030 \\
\hline & $(-3.30)$ & $(-0.882)$ \\
\hline \multirow[t]{2}{*}{$\mathrm{LEV}^{*} \mathrm{CFO}{ }^{*} \mathrm{DCFO}$} & $0.7287^{\star * *}$ & $0.7166^{\star * \star}$ \\
\hline & $(4.79)$ & $(3.15)$ \\
\hline \multirow[t]{2}{*}{ MTB } & $0.0109^{* * *}$ & -0.0072 \\
\hline & $(8.75)$ & $(-0.99)$ \\
\hline \multirow[t]{2}{*}{$\mathrm{MTB}{ }^{*} \mathrm{CFO}$} & $0.0290^{\star * *}$ & $0.1043^{\star \star \star}$ \\
\hline & $(6.30)$ & $(2.67)$ \\
\hline \multirow[t]{2}{*}{$\mathrm{MTB} * \mathrm{DCFO}$} & $-0.0055^{\star *}$ & $0.0186^{* *}$ \\
\hline & $(-2.01)$ & $(2.43)$ \\
\hline
\end{tabular}




\begin{tabular}{ccc} 
Continued & & \\
\hline $\mathrm{MTB}{ }^{*} \mathrm{CFO}{ }^{*} \mathrm{DCFO}$ & -0.0052 & $-0.0788^{*}$ \\
& $(-0.25)$ & $(-1.95)$ \\
Constant & $-0.3351^{* * *}$ & -0.1914 \\
& $(-13.30)$ & $(-0.87)$ \\
Year & YES & YES \\
Industry & YES & YES \\
Observations & 8931 & 5823 \\
R-squared & 0.945 & 0.994 \\
Adjust_R & 0.945 & 0.994 \\
\hline
\end{tabular}

Notes: $t$ statistics in parentheses, ${ }^{*} \mathrm{p}<0.10,{ }^{* *} \mathrm{p}<0.05,{ }^{* * *} \mathrm{p}<0.01$.

significantly negative $\left(\beta_{7}=-0.1482, t=-2.61\right)$. It shows that in private enterprises, the impact of corporate strategic deviance on accounting conservatism is significant, and the greater the corporate strategic deviance, the lower the accounting conservatism.

\subsection{Robustness Test}

\subsubsection{Robustness Test I}

The measurement of corporate strategic differences was based on the practice of Tang (2011). Only four indicators such as capital intensity, degree of fixed asset renewal, period cost input, and corporate financial leverage were used to measure the company's strategy, and the degree of strategic diversification of the company was obtained. Table 7 explains the corresponding variables and adopts Model 2 to test the hypotheses again. Except for the corporate strategic difference indicators, the definitions of other variables are the same as Table 2.

Since the test model is consistent with the previous model, the results of the report are omitted here to take into account the space factor, and only the main variable coefficients are explained. Among them, the coefficient of $\mathrm{SD} 2{ }^{*} \mathrm{CFO}$ * DCFO was significantly negative $\left(\beta_{7}=-0.1541, t=-2.57\right)$, indicating that there was a significant negative correlation between corporate strategy deviance and accounting conservatism, which was consistent with the hypothesis. In addition, the coefficient of SIZE ${ }^{*} \mathrm{CFO}{ }^{*} \mathrm{DCFO}$ was significantly negative $\left(\beta_{11}=-0.1607, t\right.$ $=-2.28)$, indicating that the scale of the firm was negatively correlated with the accounting conservatism. The coefficient of LEV ${ }^{*} \mathrm{CFO}{ }^{*} \mathrm{DCFO}$ is significantly positive $\left(\beta_{15}=0.7381, t=3.38\right)$, indicating that the company's asset-liability ratio is positively correlated with the accounting conservatism. The higher the enterprise's financial leverage, the stronger the accounting conservatism. The coefficient of $\mathrm{MTB}{ }^{*} \mathrm{CFO}{ }^{*} \mathrm{DCFO}$ is significantly negative $\left(\beta_{19}=-0.0772, t=-2.15\right)$, indicating that the company's market-book ratio is negatively correlated with accounting conservatism. 
Table 7. Business strategy indicators-robustness test I.

\begin{tabular}{ccc}
\hline Capital intensity & S1 & Fixed assets/employees \\
Renewed fixed assets & S2 & Net fixed assets/original value of fixed assets \\
Period cost input & S3 & Management fee/operating income \\
$\begin{array}{c}\text { Corporate financial } \\
\text { leverage }\end{array}$ & S4 & $\begin{array}{c}\text { (Short-term loans + long-term loans + bonds payable)/net assets } \\
\begin{array}{c}\text { Corporate strategic } \\
\text { deviance }\end{array}\end{array}$ \\
SD2 & $\begin{array}{c}\text { S1-S4 are summed after industry standardization respectively, } \\
\text { then absolute value is calculated, and finally averaged }\end{array}$ \\
\hline
\end{tabular}

\subsubsection{Robustness Test II}

The measurement of accounting conservatism uses the time series model of surplus proposed by Ball and Shivakumar (2005) as follows (Model 3). In the formula, $\Delta \mathrm{NI}$ is the change in net profit divided by the total assets at the beginning of the period. $\mathrm{D} \Delta \mathrm{NI}$ is a dummy variable. When $\Delta \mathrm{NI}$ is negative, $\mathrm{D} \Delta \mathrm{NI}$ takes the value 1 , otherwise it takes the value 0 , and $\beta_{3}$ is negative means that the company confirms the losses more timely, that is, the existence of accounting conservatism in the company. Model 4 is a test of the robustness of the main regression. It is expected that the sign of $\beta_{7}$ is positive, indicating that the greater the strategic deviance of the firm, the lower the accounting conservatism.

Model 3:

$$
\Delta \mathrm{NI}_{t}=\beta_{0}+\beta_{1} \Delta \mathrm{NI}_{t-1}+\beta_{2} \mathrm{D} \Delta \mathrm{NI}_{t-1}+\beta_{3} \Delta \mathrm{NI}_{t-1} \times \mathrm{D} \Delta \mathrm{NI}_{t-1}+\varepsilon_{i, t}
$$

Model 4 (the definition of other variables is the same as model 2):

$$
\begin{aligned}
\Delta \mathrm{NI}_{\mathrm{t}}= & \beta_{0}+\beta_{1} \Delta \mathrm{NI}_{t-1}+\beta_{2} \mathrm{D} \Delta \mathrm{NI}_{\mathrm{t}-1}+\beta_{3} \Delta \mathrm{NI}_{t-1} \times \mathrm{D} \Delta \mathrm{NI}_{t-1}+\beta_{4} \mathrm{SD}+\beta_{5} \mathrm{SD} \times \Delta \mathrm{NI}_{t-1} \\
& +\beta_{6} \mathrm{SD} \times \mathrm{D} \Delta \mathrm{NI}_{t-1}+\beta_{7} \mathrm{SD} \times \Delta \mathrm{NI}_{t-1} \times \mathrm{D} \Delta \mathrm{NI}_{t-1}+\beta_{8} \mathrm{SIZE}+\beta_{9} \mathrm{SIZE} \times \Delta \mathrm{NI}_{t-1} \\
& +\beta_{10} \mathrm{SIZE} \times \mathrm{D} \Delta \mathrm{NI}_{t-1}+\beta_{11} \mathrm{SIZE} \times \Delta \mathrm{NI}_{t-1} \times \mathrm{D} \Delta \mathrm{NI}_{t-1}+\beta_{12} \mathrm{LEV}+\beta_{13} \mathrm{LEV} \\
& \times \Delta \mathrm{NI}_{t-1}+\beta_{14} \mathrm{LEV} \times \mathrm{D} \Delta \mathrm{NI}_{\mathrm{t}-1}+\beta_{15} \mathrm{LEV} \times \Delta \mathrm{NI}_{t-1} \times \mathrm{D} \Delta \mathrm{NI}_{t-1}+\beta_{16} \mathrm{MTB} \\
& +\beta_{17} \mathrm{MTB} \times \Delta \mathrm{NI}_{t-1}+\beta_{18} \mathrm{MTB} \times \mathrm{D} \Delta \mathrm{NI}_{t-1}+\beta_{19} \mathrm{MTB} \times \Delta \mathrm{NI}_{t-1} \times \mathrm{D} \Delta \mathrm{NI}_{t-1}+\varepsilon_{i, t}
\end{aligned}
$$

Table 8 shows the results of the accounting stability sensitivity test. In model 3 (results are in the second column of Table 8), we expect that the sign of $\Delta \mathrm{NI}_{t-1}$ * $\mathrm{D} \Delta \mathrm{NI}_{t-1}$ is negative and the test result is in line with expectations $(\beta 3=$ $-1.1261, t=-29.43$ ), indicating there exits accounting conservatism in the sample data. For model 4 (results are in the third column of Table 8), the sign of SD ${ }^{*} \Delta \mathrm{NI}_{t-1}{ }^{*} \mathrm{D} \Delta \mathrm{NI}_{t-1}$ is expected to be positive, and the empirical test results are in line with expectations $\left(\beta_{7}=0.1095, t=5.00\right)$. It shows that there is a significant negative correlation between corporate strategy deviance and accounting conservatism, which validates hypothesis one. In addition, the fourth and fifth columns of Table 8 are the results of tests conducted on state-owned and private enterprises, respectively. The conclusion shows that in the state-owned enterprises, there is no significant correlation between corporate strategy deviance and accounting conservatism $\left(\beta_{7}=-0.1662, t=-1.30\right)$; in private enterprises, there is a significant negative correlation between corporate strategy deviance and accounting conservatism ( $\left.\left.\beta_{7}=0.7970\right), t=6.67\right)$. 
Table 8. Robustness test II results.

\begin{tabular}{|c|c|c|c|c|}
\hline Variables & Model $3 \Delta \mathrm{NI}_{t}$ & Model $4 \Delta \mathrm{NI}_{t}$ & $\begin{array}{c}\text { State-owned } \\
\text { enterprises }\end{array}$ & $\begin{array}{c}\text { Private } \\
\text { enterprise }\end{array}$ \\
\hline \multirow[t]{2}{*}{$\Delta \mathrm{NI}_{t-1}$} & $-0.0214^{*}$ & -0.2480 & -1.3302 & 0.1513 \\
\hline & $(-2.31)$ & $(-1.12)$ & $(-1.38)$ & $(0.22)$ \\
\hline \multirow[t]{2}{*}{$\mathrm{D} \Delta \mathrm{NI}_{t-1}$} & $-0.0302^{* * *}$ & $-0.2905^{\star * *}$ & $-0.3782^{*}$ & -0.2427 \\
\hline & $(-10.72)$ & $(-5.53)$ & $(-2.43)$ & $(-1.74)$ \\
\hline \multirow[t]{2}{*}{$\Delta \mathrm{NI}_{t-1} * \mathrm{D} \Delta \mathrm{NI}_{t-1}$} & $-1.1261^{\star \star \star}$ & $-8.9570^{\star * \star}$ & $-7.5326^{\star * \star}$ & 0.3963 \\
\hline & $(-29.43)$ & $(-12.26)$ & $(-3.49)$ & $(0.19)$ \\
\hline \multirow[t]{2}{*}{ SD } & & $0.0043^{\star * *}$ & -0.0108 & -0.0028 \\
\hline & & $(3.64)$ & $(-1.42)$ & $(-0.34)$ \\
\hline \multirow[t]{2}{*}{$\mathrm{SD}^{*} \Delta \mathrm{NI}_{t-1}$} & & $-0.0293^{* *}$ & 0.0598 & 0.0431 \\
\hline & & $(-3.25)$ & $(0.58)$ & $(0.47)$ \\
\hline \multirow[t]{2}{*}{$\mathrm{SD} * \mathrm{D} \Delta \mathrm{NI}_{t-1}$} & & 0.0015 & -0.0052 & $0.0697^{* * *}$ \\
\hline & & $(0.76)$ & $(-0.44)$ & $(6.66)$ \\
\hline \multirow[t]{2}{*}{$\mathrm{SD} * \Delta \mathrm{NI}_{t-1} * \mathrm{D} \Delta \mathrm{NI}_{t-1}$} & & $0.1095^{\star * *}$ & -0.1662 & $0.7970^{* * *}$ \\
\hline & & $(5.00)$ & $(-1.30)$ & $(6.67)$ \\
\hline \multirow[t]{2}{*}{ SIZE } & & $0.0106^{* * *}$ & 0.0069 & $0.0086^{*}$ \\
\hline & & $(6.83)$ & $(1.41)$ & $(2.04)$ \\
\hline \multirow[t]{2}{*}{$\operatorname{SIZE}^{\star} \Delta \mathrm{NI}_{t-1}$} & & 0.0094 & 0.0571 & -0.0081 \\
\hline & & $(1.06)$ & $(1.41)$ & $(-0.28)$ \\
\hline \multirow[t]{2}{*}{$\mathrm{SIZE}^{*} \mathrm{D} \Delta \mathrm{NI}_{t-1}$} & & $0.0134^{* * *}$ & $0.0211^{\star *}$ & 0.0018 \\
\hline & & $(5.78)$ & $(3.06)$ & $(0.30)$ \\
\hline \multirow[t]{2}{*}{$\mathrm{SIZE}^{*} \Delta \mathrm{NI}_{t-1} * \mathrm{D} \Delta \mathrm{NI}_{t-1}$} & & $0.3799^{* * *}$ & $0.3194^{\star * *}$ & -0.0776 \\
\hline & & (11.61) & $(3.35)$ & $(-0.85)$ \\
\hline \multirow[t]{2}{*}{ LEV } & & 0.0031 & $0.1081^{* * *}$ & -0.0187 \\
\hline & & $(0.47)$ & $(6.14)$ & $(-0.66)$ \\
\hline \multirow[t]{2}{*}{$\mathrm{LEV}^{*} \Delta \mathrm{NI}_{t-1}$} & & 0.0292 & 0.0138 & 0.0218 \\
\hline & & $(1.87)$ & $(0.18)$ & $(0.15)$ \\
\hline \multirow[t]{2}{*}{$\mathrm{LEV} * \mathrm{D} \Delta \mathrm{NI}_{t-1}$} & & $-0.0446^{* * *}$ & $-0.1862^{\star * *}$ & $0.2200^{* * *}$ \\
\hline & & $(-4.49)$ & $(-6.86)$ & $(6.60)$ \\
\hline \multirow[t]{2}{*}{$\mathrm{LEV}^{\star} \Delta \mathrm{NI}_{t-1}{ }^{*} \mathrm{D} \Delta \mathrm{NI}_{t-1}$} & & $-0.4224^{\star \star \star}$ & $-0.3594^{\star}$ & $-0.7371^{\star * *}$ \\
\hline & & $(-11.83)$ & $(-2.29)$ & $(-4.15)$ \\
\hline \multirow[t]{2}{*}{ MTB } & & $0.0102^{\star * *}$ & $0.0185^{\star * *}$ & 0.0068 \\
\hline & & $(8.12)$ & $(4.54)$ & $(1.50)$ \\
\hline \multirow[t]{2}{*}{$\mathrm{MTB} * \Delta \mathrm{NI}_{t-1}$} & & 0.0020 & -0.0339 & -0.0221 \\
\hline & & $(0.40)$ & $(-0.91)$ & $(-0.70)$ \\
\hline \multirow[t]{2}{*}{$\mathrm{MTB}^{*} \mathrm{D} \Delta \mathrm{NI}_{t-1}$} & & 0.0020 & -0.0019 & $0.0134^{\star}$ \\
\hline & & $(0.97)$ & $(-0.34)$ & $(2.04)$ \\
\hline
\end{tabular}




\begin{tabular}{ccccc} 
Continued & & & \\
\hline $\mathrm{MTB}^{*} \Delta \mathrm{NI}_{t-1}{ }^{*} \mathrm{D} \Delta \mathrm{NI}_{t-1}$ & & $0.0862^{\star * *}$ & 0.1011 & $0.1505^{* *}$ \\
Constant & -0.0194 & $-0.2669^{* * *}$ & $-0.2463^{\star}$ & -0.2037 \\
& $(-1.22)$ & $(-7.07)$ & $(-2.15)$ & $(-1.45)$ \\
Year & YES & YES & YES & YES \\
Industry & YES & YES & YES & YES \\
Observations & 14638 & 14638 & 1998 & 2939 \\
$\mathrm{~F}$ & 13.1885 & 18.7819 & 5.2635 & 9.5487 \\
R-squared & 0.0723 & 0.1165 & 0.1971 & 0.2419 \\
Adjust_R & 0.0639 & 0.110 & 0.1597 & 0.2166 \\
\hline
\end{tabular}

Notes: $t$ statistics in parentheses, ${ }^{*} \mathrm{p}<0.10,{ }^{* *} \mathrm{p}<0.05,{ }^{* * *} \mathrm{p}<0.01$.

\section{Conclusions, Recommendations and Outlook}

\subsection{Research Conclusions}

This article mainly studies the relationship between corporate strategic deviance and accounting conservatism, and selects the data of China's A-share listed companies from 2000 to 2016 as research samples. The company's strategy is measured by six indicators: capital intensity, degree of renewed fixed assets, period cost input, corporate financial leverage, sales expense ratio, and ratio of intangible assets, then uses the degree of deviation from industry standardization calculations and the industry, and finally comes to the strategic deviance of the company, at the same time, using the model of accrued cash flow of Ball and Shivakumar (2005) to measure the accounting conservatism. The results prove that the corporate strategic deviance of listed companies in China is inversely proportional to accounting conservatism, and this relationship is significant in private enterprises and disappears in state-owned enterprises.

At present, most of the existing researches focus on the influence of financial accounting information and high-level management characteristics on accounting conservatism in corporate governance factors. This article examines the impact of corporate strategy deviation from industry on accounting conservatism. Research shows that the greater the degree to which companies deviate from the industry's conventional strategies, the lower the degree of accounting conservatism, indicating that companies that differ in their strategic choices will increase their business risks while increasing their accounting risks. In China, many small and medium-sized investors may not understand the financial statements of listed companies because they lack relevant expertise. However, from a variety of sources, such as the news media, it may be possible to gain exposure to strategic information of the company and thus understand the company's strategy. Therefore, the conclusion of this study can provide a more convenient perspective for the decision-making of small and medium investors. 
While China's economic development is in a transitional phase and the 40th anniversary of the reform and opening-up is on the threshold, a company which wants to win in a highly competitive market environment may choose a strategy that deviates from the industry's routine. However, the choice of strategies for deviance will inevitably bring about corresponding negative impacts while enhancing the competitiveness of enterprises. The research conclusions of this paper show that those companies with higher degree of strategic deviance will have lower accounting conservatism, which will, to a certain extent, adversely affect the relationship between the company and external stakeholders and damage the interests of external stakeholders. However, the special system of state-owned enterprises weakens the conduction relationship between corporate strategic deviance and accounting conservatism.

\subsection{Policy Suggestions}

1) Improve the company's internal governance mechanism

Under the modern corporate governance system, the company's ownership and management rights are separated. There are often many conflicts of interest between the company's management and shareholders. Management may choose to deviate from the industry's conventional strategy to achieve better performance than the industry average. However, during the implementation of the strategy, in order to obtain short-term benefits, it may choose more radical accounting treatment methods and weaken the accounting conservatism, thus misleading investors' decisions and damaging the interests of investors. In the future, the corporate governance system should focus on strengthening the interests of business operators and owners, strengthen the channel for information transmission, enhance corporate value, and protect the interests of small and medium investors.

2) Improve the information disclosure system

On the one hand, small and medium-sized investors in the company lack a channel for understanding company information. On the other hand, they lack the professional ability to identify corporate accounting information. Therefore, in perfecting the information disclosure system, regulators should focus on protecting the interests of small and medium-sized investors so that small and medium investors can understand the situation of a company through more channels and more concise disclosure methods, so as to optimize decision-making.

3) Reform of the enterprise ownership system

The state-owned enterprise reform system now advancing aims to achieve a decisive role for the market in resource allocation, so that the state-owned economy can better integrate with the market economy. In mixed ownership reform, the introduction of strategic investors in the market will enrich the ownership structure of state-owned enterprises. However, the conclusion of this paper can provide suggestions on the reform of the ownership system of enterprises from another level. The introduction of state-owned shares in private enterprises is appropriate to reduce the business risk of the enterprise. 


\subsection{Future Research Prospects}

1) The impact of corporate strategic deviance on accounting information is a relatively new area of research, the impact of corporate strategic deviance in existing research is focusing on corporate performance, accounting information value, earnings management, etc. In addition to the influence of corporate strategic deviance on accounting conservatism discussed in this paper, it is also possible to study the degree of influence of corporate strategic deviance on other aspects of accounting information.

2) Due to the particularity of the system, the relationship between corporate strategic deviance and accounting conservatism is not significant in China's state-owned enterprises. Perhaps it can be revealed that in China's state-owned enterprises, the transmission mechanism of non-accounting information to accounting information is blocked, resulting in its causes. Follow-up research can be discussed.

\section{References}

[1] Meyer, J.W. and Rowan, B. (1977) Institutionalized Organizations: Formal Structure as Myth and Ceremony. American Journal of Sociology, 83, 340-363. https://doi.org/10.1086/226550

[2] Carpenter, M.A. (2000) The Price of Change: The Role of CEO Compensation in Strategic Variation and Deviation from Industry Strategy Norms. Journal of Management, 26, 1179-1198. https://doi.org/10.1177/014920630002600606

[3] Thompson, J.D. (1967) Organizations in Action: Social Science Bases of Administrative Theory. Transaction Publishers, Piscataway, New Jersey.

[4] Walton, R.E. and Dutton, J.M. (1969) The Management of Interdepartmental Conflict: A Model and Review. Administrative Science Quarterly, 14, 73-84.

https://doi.org/10.2307/2391364

[5] Geletkanycz, M.A. and Hambrick, D.C. (1997) The External Ties of Top Executives: Implications for Strategic Choice and Performance. Administrative Science Quarterly, 42, 654-681. https://doi.org/10.2307/2393653

[6] Deephouse, D.L. (1999) To Be Different, or to Be the Same? It's a Question (and Theory) of Strategic Balance. Strategic Management Journal, 20, 147-166. https://doi.org/10.1002/(SICI)1097-0266(199902)20:2<147::AID-SMJ11>3.0.CO;2Q

[7] Cannon, W.B., McIver, M.A. and Bliss, S.W. (1924) Studies on the Conditions of Activity in Endocrine Glands: XIII. A Sympathetic and Adrenal Mechanism for Mobilizing Sugar in Hypoglycemia. American Journal of Physiology-Legacy Content, 69, 46-66. https://doi.org/10.1152/ajplegacy.1924.69.1.46

[8] Beaver, W.H. and Ryan, S.G. (2005) Conditional and Unconditional Conservatism: Concepts and Modeling. Review of Accounting Studies, 10, 269-309. https://doi.org/10.1007/s11142-005-1532-6

[9] Basu, S. (1997) The Conservatism Principle and the Asymmetric Timeliness of Earnings1. Journal of Accounting and Economics, 24, 3-37. https://doi.org/10.1016/S0165-4101(97)00014-1

[10] Li, Z.Q. and Lu, W.B. (2003) The Robustness of Accounting Earnings: Discovery and Implications. Accounting Research, 2, 19-27. 
[11] Ball, R. and Shivakumar, L. (2005) Earnings Quality in UK Private Firms: Comparative Loss Recognition Timeliness. Journal of Accounting and Economics, 39, 83-128. https://doi.org/10.1016/j.jacceco.2004.04.001

[12] Hiller, N.J. and Hambrick, D.C. (2005) Conceptualizing Executive Hubris: The Role of (hyper-) Core Self-Evaluations in Strategic Decision-Making. Strategic Management Journal, 26, 297-319. https://doi.org/10.1002/smj.455

[13] Tang, J., Crossan, M. and Rowe, W.G. (2011) Dominant CEO, Deviant Strategy, and Extreme Performance: The Moderating Role of a Powerful Board. Journal of Management Studies, 48, 1479-1503. https://doi.org/10.1111/j.1467-6486.2010.00985.x

[14] Zhao, F., Wang, T.N. and Zhang, L. (2012) Empirical Research on the Effect of Diversification Strategy on Firm Performance. China Soft Science, 11, 111-122.

[15] Chen, S., Xiao, X.X., Yang, Y. and Zou, C. (2014) CEO Power, Strategic Differences and Firm Performance: A Regulatory Effect Based on Environmental Dynamics. Research in Finance and Trade, 25, 7-16.

[16] Lei, H., Wang, Y.N., Nie, S.S. and Ouyang, L.P. (2015). Research on Time Lag Effect of Competitive Strategy Performance Based on Financial Performance Composite Index. Accounting Research, 5, 64-71.

[17] Ye, K.T., Zhang, H. and Zhang, Y.X. (2014) Value Correlation between Corporate Strategy Differences and Accounting Information. Accounting Research, 5, 44-51.

[18] Ma, X.M. (2015) Corporate Strategic Differences, Information Disclosure Quality and Accounting Information Value Relevance. Doctoral Dissertation, Zhejiang Gongshang University.

[19] Ye, K.T., Dong, X.Y. and Cui, Y.J. (2015) Corporate Strategic Positioning and Accounting Earnings Management Behavior Selection. Accounting Research, 2015, 23-29.

[20] Liu, X. (2016) Does the Type of Firm's Strategy Affect the Characteristics of Earnings? A Survey of the Perspective of Accounting Conservatism. Nankai Business Review, 19, 111-121.

[21] Watts, R.L. (1993) A Proposal for Research on Conservatism.

[22] Watts, R.L. (2003) Conservatism in Accounting Part I: Explanations and Implications. Accounting Horizons, 17, 207-221.

https://doi.org/10.2308/acch.2003.17.3.207

[23] Ahmed, A.S., Billings, B.K., Morton, R.M. and Stanford-Harris, M. (2002) The Role of Accounting Conservatism in Mitigating Bondholder-Shareholder Conflicts over Dividend Policy and in Reducing Debt Costs. The Accounting Review, 77, 867-890. https://doi.org/10.2308/accr.2002.77.4.867

[24] Nikolaev, V.V. (2010) Debt Covenants and Accounting Conservatism. Journal of Accounting Research, 48, 51-89. https://doi.org/10.1111/j.1475-679X.2009.00359.x

[25] Liu, F.W. and Wang, Y. (2006) Empirical Study of the Influence of Corporate Governance Mechanisms on Accounting Conservatism. Journal of Shanghai Lixin University of Commerce, 20, 16-22.

[26] Chen, X.D. and Huang, D.S. (2007) Corporate Governance and Accounting Conservatism: Empirical Research Based on Listed Companies. Securities Market Report, 3, 10-17.

[27] Liu, Y.G., Wu, X.M. and Jiang, T. (2010) Nature of Property Rights, Debt Financing and Accounting Conservatism: Empirical Evidence from Chinese Listed Companies. Accounting Research, 1, 43-50.

[28] LaFond, R. (2005) The Influence of Ownership Structure on Earnings Conservatism 
and the Informativeness of Stock Prices: An International Comparison. Sloan School of Management. Working Paper.

[29] Cao, Y., Li, L. and Sun, J. (2005) Empirical Study of the Influence of Corporate Control on the Soundness of Accounting Earnings. Economic Management, 14, $34-42$.

[30] Fang, H.X. and Zhang, Z.P. (2012) Internal Control Quality and Accounting Conservatism: Evidence from the 2007-2010 Annual Report of Shenzhen A Share Company. Auditing and Economic Research, 5.

[31] Ahmed, A.S. and Duellman, S. (2007) Accounting Conservatism and Board of Director Characteristics: An Empirical Analysis. Journal of Accounting and Economics, 43, 411-437. https://doi.org/10.1016/j.jacceco.2007.01.005

[32] LaFond, R. and Watts, R.L. (2008) The Information Role of Conservatism. The Accounting Review, 83, 447-478. https://doi.org/10.2308/accr.2008.83.2.447

[33] Zhang, Z.G., Liu, Y.L. and Tan, D.J. (2011) Managerial Background Characteristics and Accounting Conservatism: Empirical Evidence from Chinese Listed Companies. Accounting Research, 7, 11-18.

[34] Ahmed, A.S. and Duellman, S. (2013) Managerial Overconfidence and Accounting Conservatism. Journal of Accounting Research, 51, 1-30. https://doi.org/10.1111/j.1475-679X.2012.00467.x

[35] Sun, G.G. and Zhao, J.Y. (2014) The Nature of Property Rights Differences, Management Overconfidence and Accounting Conservatism. Accounting Research, 5, $52-58$.

[36] Shen, Y.J., Liang, S.K. and Chen, D.H. (2013) Employee Compensation and Accounting Conservatism-Based on Empirical Evidence from Chinese Listed Companies. Accounting Research, 4, 73-80.

[37] Kellogg, R.L. (1984) Accounting Activities, Security Prices, and Class Action Lawsuits. Journal of Accounting and Economics, 6, 185-204. https://doi.org/10.1016/0165-4101(84)90024-7

[38] Ball, R., Robin, A. and Wu, J.S. (2003) Incentives versus Standards: Properties of Accounting Income in Four East Asian Countries. Journal of Accounting and Economics, 36, 235-270. https://doi.org/10.1016/j.jacceco.2003.10.003

[39] Zhou, Z.J. and Du, X.Q. (2012) Tax Burden, Accounting Conservatism and Compensation Performance Sensitivity. Financial Research, 10, 167-179.

[40] Che, F. (2012) Income Tax Reform, Accounting-Tax Differences and Accounting Conservatism. Journal of Zhongnan University of Economics and Law, 6, 93-99.

[41] Zhu, C.F. and Li, Z.W. (2008) Research on the Effect of State Holding on Accounting Conservatism. Accounting Research, 5, 38-45.

[42] Du, X.Q., Lei, Y. and Guo, J.H. (2009) Political Connections, Political Contacts, and Accounting Conservatism of Private Listed Companies. China Industrial Economy, 7, 87-97.

[43] Chen, Y.Y., Tan, Y. and Tan, J.S. (2013) Political Connections and Accounting Conservatism. Nankai Management Review, 1, 33-40.

[44] Jiang, Y. and Tian, K.R. (2013) Internal Characteristics of State-Controlled Listed Companies, Government Grants and Accounting Conservatism. Auditing and Economic Research, 1, 77-86.

[45] Lin, H. (2006) Accounting Discretion and Managerial Conservatism: An Intertemporal Analysis. Contemporary Accounting Research, 23, 1017-1041. https://doi.org/10.1506/0343-6720-V320-4730 
[46] Wang, R.Z., Ó Hogartaigh, C. and van Zijl, T. (2009) A Signaling Theory of Accounting Conservatism.

[47] Stiglitz, J.E. and Weiss, A. (1981) Credit Rationing in Markets with Imperfect Information. The American Economic Review, 71, 393-410.

[48] Mintzberg, H. (1978) Patterns in Strategy Formation. Management Science, 24, 934-948. https://doi.org/10.1287/mnsc.24.9.934

[49] Yang, H.J. (2007) A Review of Research on Accounting Conservatism. Accounting Research, 1, 4. 